811.163.41'366.593

811.163.41'35

https://doi.org/10.18485/kij.2021.68.1.11

ГОРАН Н. ЗЕЉИТ

Оригинални научни рад

Универзитет у Београду

Примљен: 17.02.2021.

Учитељски факултет

Прихваћен: 26.04.2021.

\title{
ОБЛИЦИ ИМПЕРАТИВА У ПРАВОПИСНИМ ПРИРУЧНИЦИМА СРПСКОГ ЈЕЗИКА
}

\begin{abstract}
У раду је анализирана заступљеност императивних облика у правописима српског (српскохрватског) језика, почев од Белићевих приручника (1923, 1930, 1934, 1950), преко Матичиних издања (1960, 1993, 2010), закључно са Дешићевим (2015) и Симићевим приручником (2016). Анализом је обухваћено стотину глагола који се у поменутим приручницима јављају у императиву, а који се у говорној и писаној пракси појављују и у супстандардним ликовима. Сви они распоређени су у четири групе имајући у виду њихове облике императива. То су: а) глаголи код којих у императиву долази до нестандардног губљења сонанта $j$ из наставка за облик (нпр. зали ум. залиј, покри (се) ум. покриј се); б) глаголи који у облицима императива имају нестандардно $u$ после наставка -j (нпр. броји ум. број, обоји ум. обој); в) глаголи са дублетним облицима императива (нпр. вагај и важи, дозидај и дозиђи); г) видски парњаци и њихови облици императива (нпр. дати - даj : давати - дајu, препознати - препознај : препознавати - препознаји).
\end{abstract}

Кључне речи: глаголски облици, императив, правопис, правописни речник.

\section{Увод}

О облицима императива (заповедног начина) доста је писано у граматичкој и правописној литератури. О грађењу императива са освртом на граматичке приручнике исцрпно је писао М. Стакић (Стакић 2010). У граматичким уџбеницима представљен је начин грађења императивних облика, те се, у новијим издањима, указује и на огрешења у говорној и писаној пракси (Ломпар 2011; 2014). Тако је и у језичким и правописним саветницима и приручницима (Станић 1973; Станић/Морачић 1989; Симић и др. 1998; Ивић и др. 2004). Коначно, у правописној литератури императив се обрађује у делу посвећеном графеми $j$, а неки

"goran.zeljic@uf.bg.ac.rs 
примери (поготово они којима се илуструју огрешења у пракси) представљени су у правописним речницима.

На основу уџбеничке граматичке литературе, грађење императива се у наставној пракси обрађује у осмом разреду основне школе и другом разреду средње школе. У приручницима из граматике српског језика за те разреде се, поред начина грађења, дају, срећом, и примери огрешења у пракси. Тако В. Ломпар у свом уџбенику (Ломпар 2011: 66) наводи да се овај глаголски облик гради додавањем двојаких наставака -j/-и (за 2. л. јд.) односно -јмо/-имо и -jmе/-ите за 1. и 2. лице множине на граматичку основу коју добијамо од 3. лица множине презента одбијањем наставка за облик. Поред вежбања, дато је и десет фреквентних глагола (и то најчешће оних који се у презенту завршавају на -ијем/-ојим) чији се облици императива у пракси јављају са нестандардним наставцима попут разбити (разбиј), залити (залиј), зашити (зашиј), пити (пиј), покрити (покриј), обојити (обој), раздвојити (раздвој), спојити (спој), те разумети (разумеј) и засукати (засучи). Овај списак ауторка у свом средњошколском уџбенику (Ломпар/Антић 2014: 127) допуњује и глаголима издвојити (издвој), набројати (наброј), навити (навиј), освојити (освој) и др., дајући сада и супстандардне ликове попут разуми ум. разумеј, удостоји ум. удостој итд. Такође, наведени су и глаголи помоћи, лећи и сести са дублетним ликовима помози/помогни, лези/легни и седи/седни.

У општим граматикама начин грађења је представљен, разумљиво, нешто детаљније. ${ }^{1}$ Тако се у Нормативној граматищи (Пипер/Клајн 2013: 180-182) прецизира да се наставци $-j$, -jмо, -jmе додају на основу добијену од 3. лица множине презента ако се она завршава на -jy или -je, нпр. од гл. бројати (3. л. мн. през. броје - имп. број, бројмо, бројте), веровати (верују - веруј, верујмо, верујте) и сл., док ће код мањег броја глагола који у множини презента испред наставка -jy или -jе имају дуг самогласник (наглашен или ненаглашен), императив бити на -и, -имо, -ите, нпр. блејати (3. л. мн. през. блеје - имп. блеји, блејимо, блејите), продавати (продају - имп. продаји, продајимо, продајите) и сл. (в. и Стевановић 1986: 337; Симић/Јовановић 2007: 126-127). ${ }^{2}$

Коначно, ваља напоменути да је и у граматичкој и правописној литератури било колебања око неких решења. Аргументи који су дати вероватно се могу користити и данас. Тако прво Белић у Правопису из 1923. наводи да се двојако „пише и зап. начин од једносложених глаголских основа на $u$ : nu и пиј, nuте и пијте, би и биј и сл. У изговору се ту чује само дуго $u$, те би тако требало и писати; дакле ви, зави, испи, испимо и сл.” (Белић 1923: 31)³. И М. С. Лалевић

${ }^{1}$ Подробну анализу грађења императива дао је М. Стакић у своја два веома важна рада „О грађењу императива у српском језику” и „Презент и императив у нашој науци и школској пракси” (Стакић 2010).

2 Занимљиво је да Вук у својој граматици која претходи речнику (1818) нема 1. л. мн. императива већ користи конструкцију да +1 . л. мн. презента (нпр. да лијемо ум. лијмо; 1818: LXIII; о томе и у Маретић 1899: 231 и даље).

${ }^{3}$ Код Вука Караџића такође налазимо дублетна решења од којих је једно без $j$, нпр. лйj/лй; лиิjme/лйme (1818: LXIII). 
наводи да „има глагола који би без наставка у овом облику били нејасни, необични, па им се иза завршног гласа $j$ додаје наставак -u” (Лалевић 1980: 1174), те би било нормативно обоји (од обојити), таји (од тајити), бруји (од брујити) и сл. (Исто). „Значи”, наставља Лалевић, „кад год нам се, ако правилно ствари осећамо, учини да нешто није јасно, да недостаје наставак, треба га употребити, иако таквих глагола нема много" (Исто).

\section{О огрешењима у пракси}

Видели смо да се на погрешне ликове императива указује у граматичкој уџбеничкој литератури и језичким саветницима и приручницима (в. и Брборић и др. 1999). У наставној пракси на погрешне ликове императива на примеру писмених задатака ученика указује и В. Брборић (Брборић 1998: 18) дајући облике попи (ум. попиј) и сечи (ум. сеци).

Сви ти примери погрешних решења могли би се поделити у две групе. Прву би чинили примери који су у вези са гласовним алтернацијама типа сечи ум. сеци (од 3. л. мн. през. сек + -и; алтернација к:и), вучи ум. вуц̧и (алтерн. к:ц - вук$+-u>$ вуци ), пушти ум. пусти (3. л. мн. презента пусте: nуст- + $-u>$ nусти), односно суц̧и (бркове), засуции (рукаве), исуц̧и (мач) и насуцุи 5 (брод) по погрешној аналогији с имп. типа вуци ум. сучи/засучи/исучи/насучи (3. л. мн. презента сучу/засучу/исучу/насучуб $)$ и сл., док би у другу, бројнију, били сврстани а) ликови без ј у свим лицима типа пи, пимо, пите ум. пиј (пијмо, пијте) и б) ликови са самогласником $u$ после сонанта $j$ типа обоји, обојимо, обојите ум. обој, обојмо, обојте. Управо ова друга група предмет је наше анализе.

На пример:

Пронађи, споји и освоји за више од 125.000 „кока-кола” награда (Зељић, 2020: 54). Обоји Београд (Вукомановић, 2016). „Литре броји - гориво освоји” (Топспид, децембар 2020). Открите све скривене трошкове (Блиц, 21. 2. 2006). Испрозивао Мркелу и Станковића: „Аматеру покри се ушима и ћути” (Београдски портал, 19. 9. 2020). Бекер без милости, директно се обратио Ђоковићу: „Брате, издвоји време и извуци поуке” (Телеграф, 7. 9. 2020). Емери Пауер је рекао: „Разумите, ја као и и ви, не прихватам пораз.” (Кристи 2005: 241). Разумите већ једанпут, господине, не остављам ја вама ништа. (Нушић 1996: 426). Будите гласне и храбре - не оправдавајте насиље (Ало, 25. 11. 2020). Постепено додавајте шећер (Глоси, 10. 2. 2020). „Пи воду и ћути” (Михаиловић 1994: 5) „На”, каже, „попи ово” (Исто, 263). „Па уби ме ако оћеш” (322).

${ }^{4}$ Николић је забележио шеснаест глагола са основом сукати и различитим префиксима (в. Николић 2000), а глаголе засукати, насукати, сукати, усукати унео је у свој речник и Вук Караџић (са презентом на -учем; Караџић 1818: 217, 454, 803, 873).

${ }^{5}$ Насуците ме, насуците ме, момци, на њихова црна леђа (Мелвил 1969: 273 и 2020: 292). „Насукати, през. насучем, насучу, з. н. насучи, трп. насукан” (Белић 1950: 295).

${ }^{6}$ Погрешни ликови императива ових глагола последица су погрешних ликова презента, тачније 3. л. множине, засуку, исуку, насуку ум. засучу, исучу, насучу (промена као глагол викати). 
Мишљења смо да је више разлога који доводе до ненормативних ликова императива (и то не само за 2. л. једнине, већ и за 1. и 2. л. множине). Проблем је у томе што су и огрешења о грађење императива различитог порекла. Ако погледамо табеле у наставку рада, видећемо да је један вид нестандардних решења гласовна редукција у случајевима додира сонанта $j$ у финалној позицији са сродним самогласником $u$, типа попи ум. попиј. У другом случају код императива глагола типа обојити са нормативно неприхватљивим решењем обоји ум. обој јесте управо решење које граматике дају за треће лице једнине (и множине). Наиме, конструкцију са речцом нека + презент (3. л. јд. нпр. нека оेбојӣ) чини управо презент глагола, који се онда, по угледу на саму конструкцију јавља и у 2. л. једнине (обоји), те у 1. и 2. л. множине (обојимо/обојите). Стевановић истиче да је ову конструкцију (и конструкцију везник $\partial a+$ презент глагола) могуће употребити и у осталим лицима за која постоје облици императива (Стевановић 1986: 337). Коначно, за трећи случај огрешења и то код несвршених глагола типа продавати (продаји; предавати - предаји; издавати - издаји) са самогласником $u$ после сонанта $j$ можемо рећи да се јавља као резултат коришћења инфинитивне основе уместо крње презентске, нпр. продавати: продава- + -j> продавај (ум. продаји); предавати: предава- + -j> предавај (исто издавај). На тај начин успоставља се аналошка веза између наставака за императив који се додају видским парњацима (продати - продај: продавати - *продавај).

\section{Облици императива у правописним приручницима српског (српскохрватског) језика}

За анализу примера забележених у правописним приручницима одлучили смо се с циљем да утврдимо у којој мери је овај облик (чије грађење често изазива недоумице и у пракси се бележи као нестандардан), заступљен у правописима као приручницима чија је једна од функција и разрешавање дилема које говорници могу имати.

У правописима српског (српскохрватског) језика императив се обрађује у оквиру писања сугласника (сонанта) $j$, а конкретни примери представљени су више или мање у правописним речницима датих приручника.

Анализом смо обухватили све релевантне правописне приручнике, почев од Белићевог из 1923. године закључно са Симићевим из 2016. године. У обради писања сонанта $j$ у оквиру правописних правила а у вези са облицима императива уочили смо две важне карактеристике. Испало је тако да су у обради императивних облика кључна два нормативна приручника. Први, Белићев, из 1923. године, јер показује узрок и данашњег стања у вези са облицима императива, и други, Симићев, из 2016. који је дао дотад у правописима најобимнија упутства о писању сонанта $j$ у императиву и конкретне примере за то.

Анализу смо започели примерима из Белићевог приручника из 1923. године. Видели смо да у односу на актуелну норму, Белић даје дублетне ликове за 
императив глагола пити (пи и пиј), бити (би и биј), те као нормативне препоручује данас нестандардне ви (од вити), зави (завити), испи (испити) (Белић 1923: 31). Од овог приручника, облици императива наћи ће се и у наредним издањима Белићевог правописа, али и у наредним правописним приручницима уопште. Занимљиво је још и то да је Белић у следећем издању (1930) искључио облике без $j$, те је једино нормативно било пиј, завиј и сл. (Белић 1930: 34).

Број представљених примера у делу који је посвећен правилној употреби/ писању сугласника/сонанта $j$ није се у суштини мењао, ако изузмемо Симићев правописни приручник из 2016, у коме је дато исцрпно упутство о писању овог гласа у императивним облицима (в. и Симић 1991: 91; Симић и др. 1998: 70). У упутству за писање $j$ у императиву (Симић 2016: 97), аутор систематизује упутства по угледу на она у граматичким приручницима дајући две групе глагола - оних са $j$ на крају овог облика и оних са самогласником и после сонанта $j$. У првој групи су а) глаголи који у 3 . л. множине презента имају $j$ а у осталим лицима немају, типа смејати се - 3. л. мн. смеју - имп. смеј/смиј се и сл. и б) глаголи који имају сонант $j$ у свим облицима презента попут глагола бити - бију - имп. биј. Другу групу чине глаголи који ће у императиву после $j$ имати самогласник $u$ типа предаји (и бруји од брујати, гаји од гајити, даји од давати, удаји од удавати, хуји од хујити).

У правописним речницима анализираних приручника мењао се број забележених примера императива. У табелама које следе представили смо те облике водећи рачуна управо о актуелном стању и потребама праксе.

За анализу смо издвојили четири групе глагола имајући у виду њихове облике императива. То су:

a) глаголи код којих у императиву долази до губљења сонанта $j$ из наставка за облик;

б) глаголи који у облицима императива имају нестандардно $u$ после наставка $-j$;

в) глаголи са дублетним облицима императива;

г) видски парњаци и њихови облици императива.

У Табели 1 дати су облици императива са сонантом $j$ у основи. Реч је о гла-

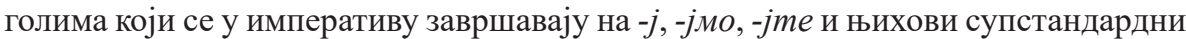
ликови из праксе. Због уштеде у простору, дато је само 2. л. једнине императива. Анализирани правописи представљени су у скраћеној форми, акронимом: Белићев правопис из 1950. године - Б50; Матичин правопис из 1960. године (ур. Стевановић/Јонке) - П60; правописни приручник Симића и др. из 1993. г. - С93; правопис Пешикана, Јерковића и Пижурице из 2010. г. - П10; правопис Милорада Дешића из 2015. г. - Д15; Симићев правопис из 2016. г. - С16. 


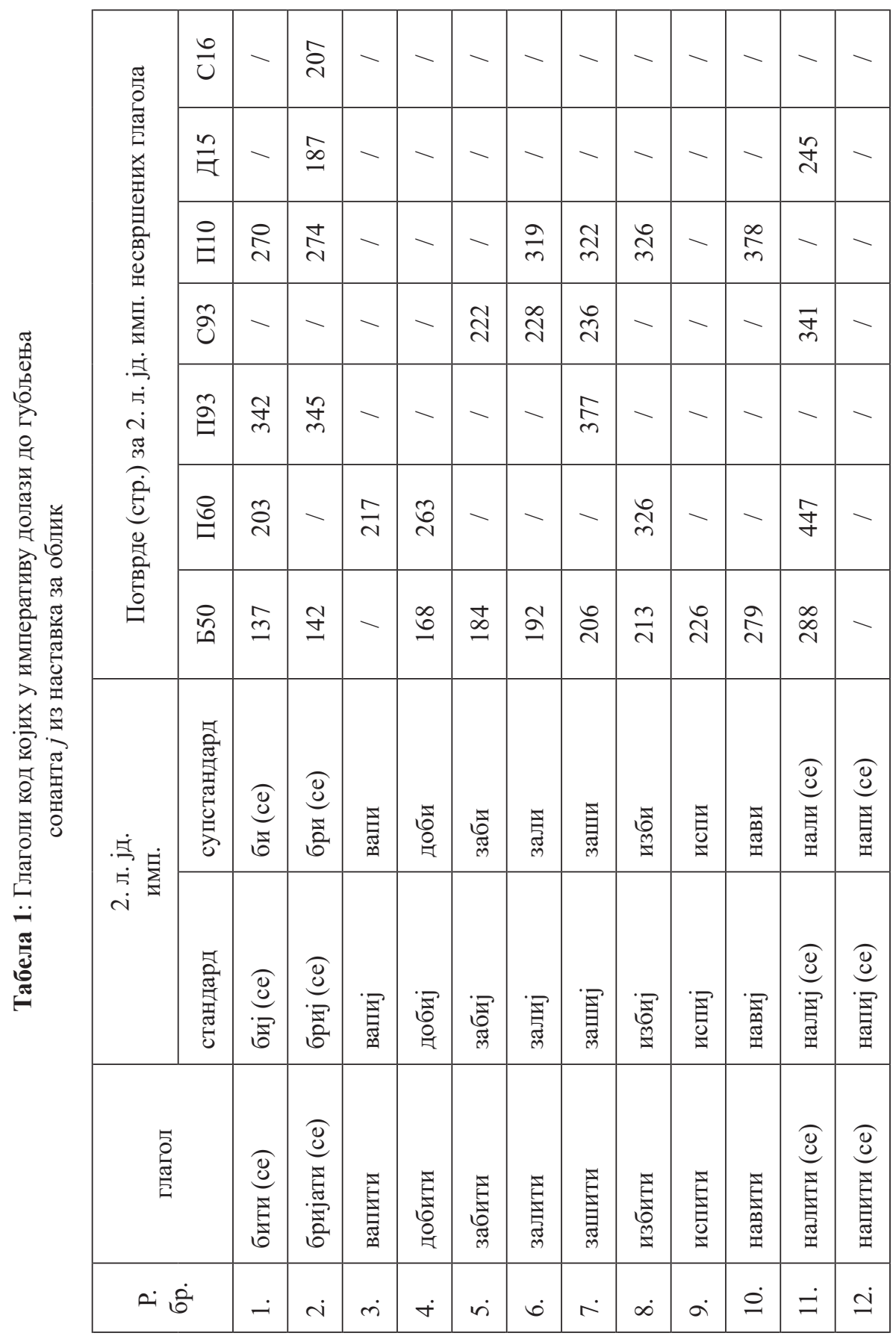




\begin{tabular}{|c|c|c|c|c|c|c|c|c|c|c|c|c|c|c|}
\hline- & - & - & - & $\frac{\infty}{\sim}$ & - & - & - & - & - & - & - & - & - & - \\
\hline- & - & - & 点 & $\tilde{n}$ & - & - & - & - & - & - & - & - & - & - \\
\hline- & ๙n & ڤn & - & oे & $\stackrel{n}{\gamma}$ & - & $\frac{\sigma}{\forall}$ & 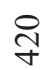 & $\underset{\Im}{\Im}$ & - & $\underset{\sim}{\widetilde{f}}$ & $\underset{\sim}{\stackrel{J}{J}}$ & 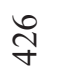 & - \\
\hline$\hat{\infty}$ & సे & - & - & 웜 & - & - & $\bar{\nabla}$ & $\stackrel{\infty}{\infty}$ & ஓ & - & - & in & - & - \\
\hline- & - & - & - & $\stackrel{\infty}{\underset{f}{f}}$ & - & - & $\stackrel{m}{\mathscr{\sigma}}$ & - & - & - & - & - & - & $\gamma$ \\
\hline- & - & - & - & $\stackrel{n}{n}$ & - & - & $\frac{0}{n}$ & - & - & - & - & ᄋి & - & - \\
\hline- & $\frac{a}{m}$ & 으 & 울 & 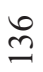 & $\underset{\infty}{\infty}$ & Oे & $\frac{m}{m}$ & $\hat{\infty}$ & $\begin{array}{l}\infty \\
\infty \\
m\end{array}$ & ๙ิ & 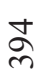 & - & ồ & $\underset{\nabla}{\nabla}$ \\
\hline ర్ & 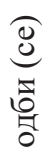 & $\begin{array}{l}\text { 总 } \\
\text { 㟧 }\end{array}$ & 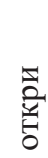 & $\Xi$ & 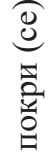 & 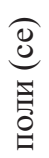 & 氙 & 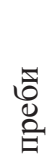 & $\begin{array}{l}\stackrel{\Xi}{0} \\
\stackrel{0}{0} \\
\stackrel{0}{\square}\end{array}$ & 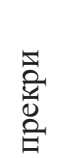 & $\begin{array}{l}\text { 寻 } \\
\text { 怘 }\end{array}$ & 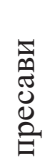 & 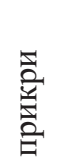 & $\begin{array}{l}\text { 臬 } \\
\text { 号 }\end{array}$ \\
\hline ': & 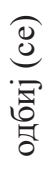 & $\begin{array}{l}\text { F्ञ } \\
\text { 영 }\end{array}$ & 疍 & $\vec{\Xi}$ & 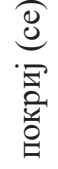 & 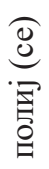 & $\begin{array}{l}\vec{\Xi} \\
\text { 罗 }\end{array}$ & 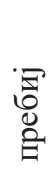 & 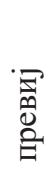 & 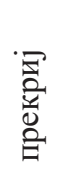 & 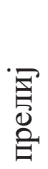 & 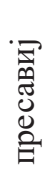 & 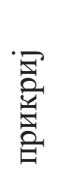 & $\begin{array}{l}\text { 录 } \\
\text { 罖 }\end{array}$ \\
\hline 疋 & 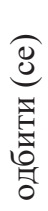 & 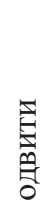 & 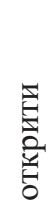 & $\underset{\Xi}{\Xi}$ & 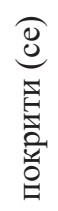 & 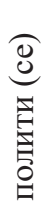 & 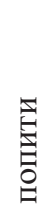 & 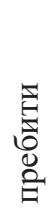 & 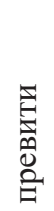 & 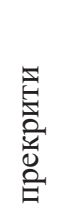 & 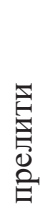 & 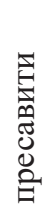 & 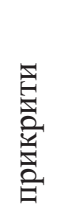 & $\begin{array}{l}\stackrel{\Xi}{\Xi} \\
\text { 罗 } \\
\text { 品 }\end{array}$ \\
\hline$\dot{\imath}$ & $\dot{\Xi}$ & $\ddot{n}$ & $\stackrel{0}{0}$ & 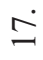 & $\infty$ & 2 & 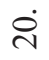 & $\vec{v}$ & ป & $\ddot{\sim}$ & $\stackrel{\Xi}{\sim}$ & ๙ & $\stackrel{0}{\sim}$ & $\hat{\sim}$ \\
\hline
\end{tabular}




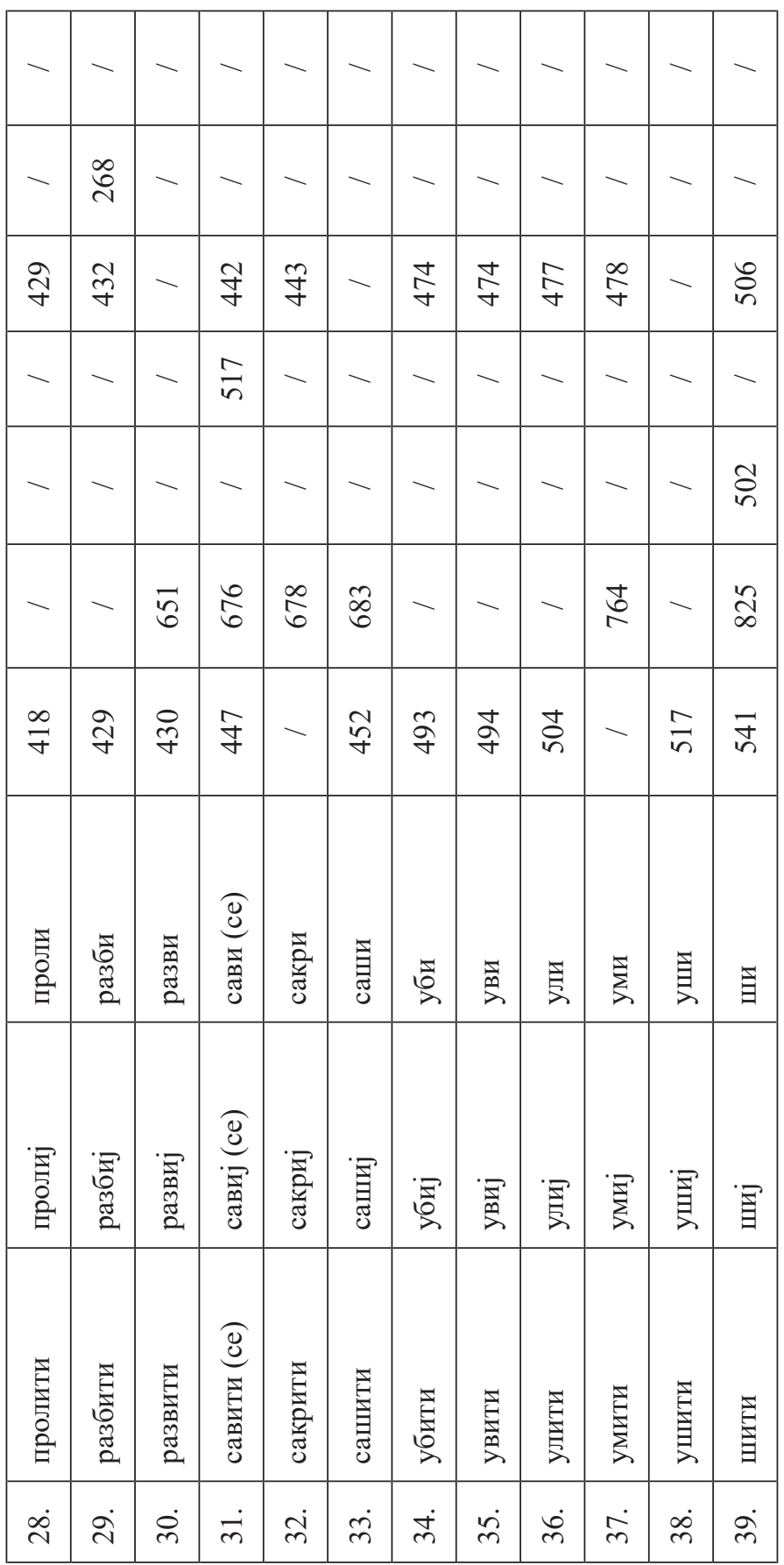


Анализом је обухваћено тридесет и девет глагола код којих долази до редукције групе $u j$ у $u$ у говорној пракси а који су забележени у правописним приручницима. Заједничко за све њих јесте дуг акценат код једносложних облика императива (нпр. бйj (ce), бриิj (ce)), односно дуг самогласник у последњем слогу код вишесложних облика императива (òdвйj, päзбйj). Видимо да је по броју глагола најобимнији правописни речник Белићевог приручника из 1950. (1952) уместо очекивано Матичиног из 1960. године. За један број глагола није дат њихов императив, већ се упућује на сродан глагол и његове глаголске облике. Тај начин обраде најзаступљенији је у П60 (нпр. на глагол сакрити (имп. сакриј - 678) упућује се за глаголе открити (се), покрити (се), прекрити (се), прикрити (се); на облике глагола избити (имп. избиј - 326) упућује се за глаголе одбити (се), пребити, разбити, убити итд.), као и П93 (нпр. на облике глагола бити, па тако и на његов императив биј (342) упућује се за глаголе забити, избити, одбити (се), пребити, убити; на глагол крити (имп. криј - 398) упућује се за глаголе покрити (се), прекрити, прикрити, сакрити; на глагол вити (имп. виј - 351) упућује се за глаголе превити (се), савити (се), увити (се) итд.); коначно, у П10 забележили смо да се за глагол забити упућује на глагол бити (имп. биј - 270), испити упућује на облике глагола пити (имп. пиј - 409) и за глаголе открити се и прекрити на гл. крити (имп. криј - 352), полити се на глагол лити (имп. лиј - 359) и ушити на шити (имп. $u и j-506)$. Неколико глагола заступљено је у правописним речницима, али нису дати њихови облици императива (нпр. у Белићевом приручнику глагол вапити наведен је у презенту, али не и у императиву). Данас фреквентни глаголи у језику реклама повити и преповити нису забележени у правописним приручницима (јесу у П60, али без императива). У П60 и Симић и др. из 1993. више је примера глагола чији облици императива нису забележени, али се они могу извести преко презента (попут поменутих глагола повити и преповити или у Симић и др. 93: 547 гл. шити - шијем).

Следећу групу чиниће глаголи који у облицима императива имају нестандардно $u$ после -j (Табела 2). 


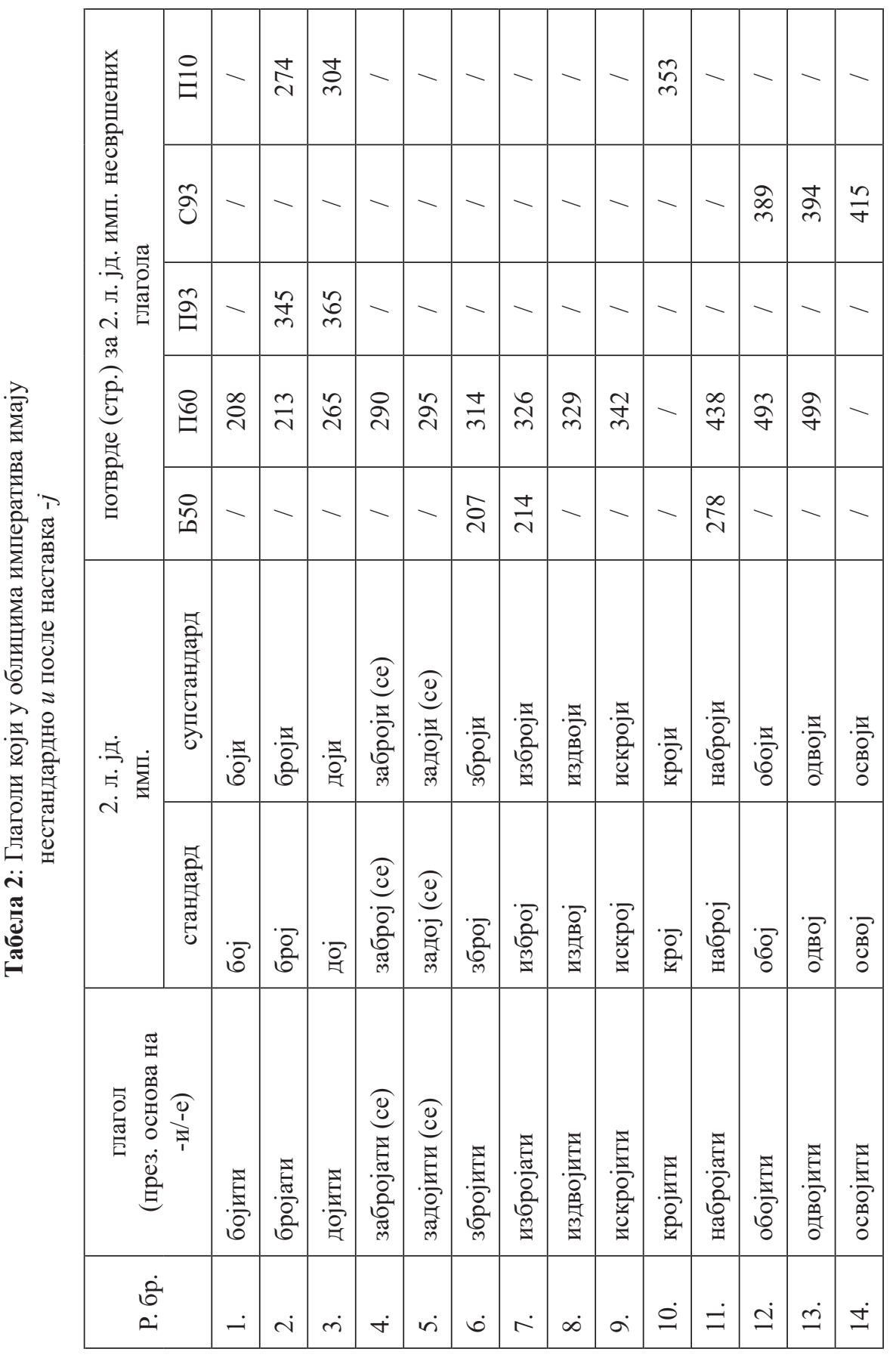




\begin{tabular}{|c|c|c|c|c|c|c|c|c|c|c|}
\hline- & - & - & - & $\stackrel{m}{\sigma}$ & $\underset{m}{+}$ & - & - & - & - & \\
\hline$\stackrel{n}{\sigma}$ & - & - & - & - & - & - & - & - & - & $\gamma$ \\
\hline- & - & - & - & - & - & - & - & - & - & - \\
\hline i & 䓃 & రి & $\begin{array}{l}\mathcal{N} \\
\text { ర్t }\end{array}$ & $\gamma$ & $\hat{\sigma}$ & જे & - & N & $n$ & $\gamma$ \\
\hline- & - & - & - & - & - & - & - & - & - & - \\
\hline $\begin{array}{l}\text { 콩 } \\
\text { 믕 }\end{array}$ & 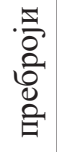 & 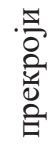 & 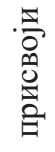 & 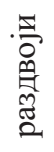 & 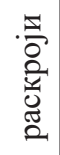 & $\begin{array}{l}\frac{5}{0} \\
\frac{2}{2} \\
\frac{2}{0}\end{array}$ & $\begin{array}{l}\frac{5}{\circ} \\
\frac{5}{0}\end{array}$ & 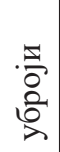 & $\begin{array}{l}\text { 홍 } \\
\text { 基 }\end{array}$ & $\begin{array}{l}\frac{\Xi}{2} \\
\frac{2}{2}\end{array}$ \\
\hline $\begin{array}{l}\overline{0} \\
\text { A } \\
0 \\
0\end{array}$ & 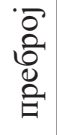 & $\begin{array}{l}\overline{0} \\
\stackrel{0}{0} \\
\stackrel{0}{0} \\
\text { : }\end{array}$ & $\begin{array}{l}\overline{0} \\
000 \\
0 \\
0 \\
0\end{array}$ & 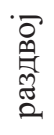 & 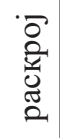 & 'ত্ঠ) & 'ত্ত' & 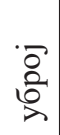 & $\begin{array}{l}\text { 웅 } \\
\text { 竞 }\end{array}$ & 客 \\
\hline 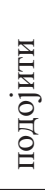 & 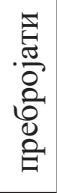 & 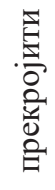 & 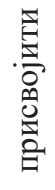 & 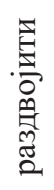 & 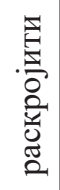 & 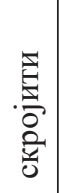 & 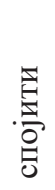 & 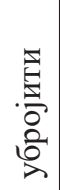 & 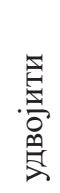 & 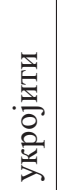 \\
\hline s & 6 & - & $\infty$ & 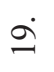 & 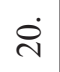 & $\vec{\sim}$ & $\widetilde{N}$ & $\hat{\imath}$ & $\stackrel{\sim}{\sim}$ & N \\
\hline
\end{tabular}


У овој групи глагола у презенту самогласник испред $j$ је кратак, нпр. $\grave{о б о ј \bar{u} м, \text { те су наставци за императив }-\varnothing^{7},-м о,-m е ~(3 . ~ л . ~ м н . ~ п р е з . ~ б р о ̀ j е ̄ ~-~ и м п . ~}$ број-ø, исто искрој, обој и сл.). У једносложним облицима императива акценат је дуг (брôj), као и самогласник у финалном слогу код вишесложних императивних облика (нпр. приेсво̄j). У табелу нису увршћени Дешићев и Симићев правопис јер у првом забележен је само императив глагола освојити (освој; Дешић 2015: 254), а у Симићевом бојити (бој; Симић 2016: 186). Као и у претходној табели, и овде се за неколико глагола не дају њихови облици, већ се упућује на сродне глаголе (нпр. у П60 за облике гл. освојити упућује се на глагол наточити (имп. наточи - 455); у П10 за глагол забројати се упућује се на глагол бројати (имп. број - 274), за глагол подојити даје се гл. дојити (имп. доj-304), те за глаголе искројити, прекројити и скројити упућује се на глагол кројити (имп. крој-353).

Сродност ове групе с претходном је у томе што је опет дошло до својеврсног кориговања (наравно супстандардног) наставка за императив додавањем финалног самогласника $u$, чиме смо добили још један, видели смо већи, број глагола који се у 2. л. једнине завршавају тим гласом. Тако имамо имп. обоји, који се „уклапа” са стандардним облицима глагола типа доћи (имп. дођи, исто реци, сеци, види, носи и сл.), као што је то урађено и у претходној групи редукцијом сонанта $j$ (пи, сави, уми, уши и сл.).

Ако овоме додамо и нестандардна решења типа оправдавај (од оправдавати) ум. оправдаји (исто *издавај, *nредавај, *nродавај), можемо закључити да су се у пракси (говорној и писаној) наметнула два лика императива:

на $-u$

a) стандардни (типа рец̧и, види и сл.);

б) нестандардни (типа пи, ущии, обоји, споји и сл.).

на - - j

a) стандардни (типа гледај, помагај и сл.);

б) нестандардни (типа издавај, оправдавај, сазнавај, али и машај ум. маши и сл.).

У следећој табели (Табела 3) дати су глаголи с дублетним наставцима у императиву.

\footnotetext{
${ }^{7}$ В. Стакић 2010: 133.
} 


\begin{tabular}{|c|c|c|c|c|c|c|c|c|c|c|c|c|c|c|c|}
\hline & $\stackrel{n}{E}$ & - & - & - & - & - & - & - & - & - & - & తి & - & - & - \\
\hline 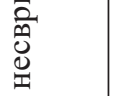 & $\stackrel{\circ}{\Xi}$ & $\frac{2}{\sqrt{v}}$ & - & - & - & - & - & - & - & - & - & $\ddot{m}$ & $\gamma$ & - & - \\
\hline 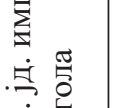 & $\hat{\jmath}$ & - & - & - & $\underset{m}{m}$ & $\hat{n}$ & ஓ̊ & - & - & - & - & - & - & - & - \\
\hline 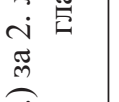 & $\hat{\sigma}$ & 守 & - & - & - & - & - & - & - & $\gamma$ & - & - & - & - & - \\
\hline$\underbrace{5}_{0}$ & $\stackrel{8}{8}$ & $\stackrel{\bullet}{\sim}$ & $\underset{\sim}{\sim}$ & $\underset{\mathfrak{d}}{\sim}$ & $\stackrel{\text { f }}{f}$ & - & $\ddot{6}$ & $\frac{0}{6}$ & $\frac{\nabla}{\sigma}$ & $\frac{\partial}{\sigma}$ & $\frac{9}{6}$ & - & రై & $\frac{\infty}{6}$ & $\frac{\infty}{6}$ \\
\hline & $\stackrel{\circ}{\circ}$ & - & - & - & N & - & - & - & - & - & - & - & - & - & - \\
\hline \multirow{2}{*}{ 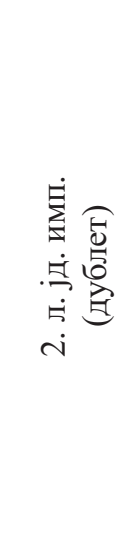 } & & 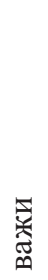 & 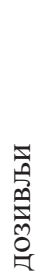 & 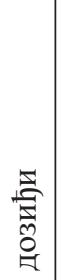 & 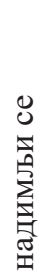 & 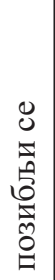 & 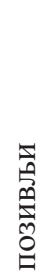 & 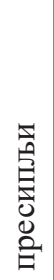 & 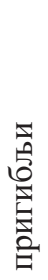 & 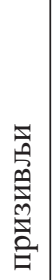 & 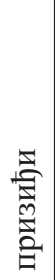 & 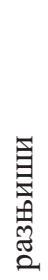 & 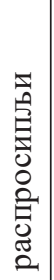 & 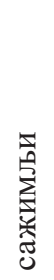 & 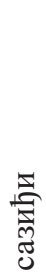 \\
\hline & & 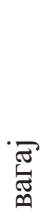 & 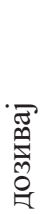 & 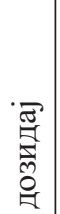 & 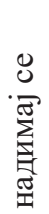 & 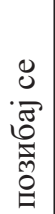 & 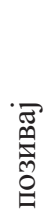 & 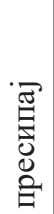 & 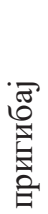 & 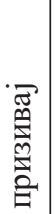 & 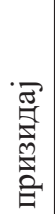 & 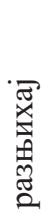 & 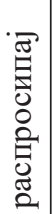 & 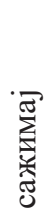 & 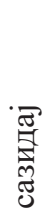 \\
\hline 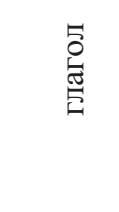 & & 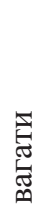 & 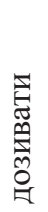 & 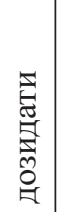 & 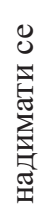 & 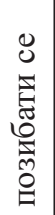 & 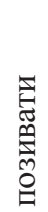 & 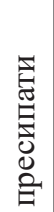 & 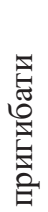 & 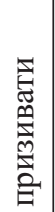 & 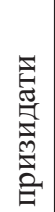 & 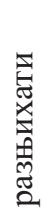 & 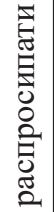 & 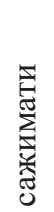 & 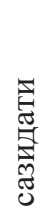 \\
\hline ن & & $-\dot{ }$ & ن & $\dot{m}$ & $\dot{\forall}$ & $\dot{r}$ & $\dot{0}$ & $\sim^{\circ}$ & $\infty$ & $a^{\circ}$ & 으 & $\doteq$ & 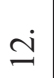 & $\cong$ & \pm \\
\hline
\end{tabular}


Ову групу чине глаголи који имају дублетне облике у презенту (нпр. дозивати - дозивам/дозивљем), па тако и различите наставке у императиву. У Симићевом правопису нисмо нашли примере глагола са дублетним наставцима у императиву. Анализом су обухваћени глаголи чија је презентска основа на - $a$, нпр. вагати - вага- (вагам, вагаш, вага итд.), док се императив гради од 3 л. мн. вагају одбијањем -у и додавањем наставака -ø, -мо, -те: вагај, вагајмо, вагајте. Други императивни лик добијен је додавањем наставака -u, -имо, -ите на основу добијену од презента у коме је ненепчани и задњонепчани сугласник испред $e$ замењен својим јотованим алтернантом (нпр. 3. л. мн. през. дозиђу: дозиђ- $+-u>$ имп. дозиђи). И у овој табели - али у мањој мери, јер је и мање глагола са дублетним наставцима у императиву - у неколико примера упућује се на сродне глаголе и њихове облике. Такође, за неке глаголе нису наведени облици императива, али се дају дублетни наставци за презент, те се може закључити да су им и императивни облици дублетни (нпр. у правопису Симића и др. 1993. глагол дозивати је забележен, али само са дубл. обликом презента дозивам/дозивљем (205), на основу којег се може закључити и да је имп. дублетан - дозивај/дозивљи; исто и у Белић 1950: 170 као и позивати (365), призивати (405), призидати (405) и сажимати (448), док је за глагол сазидати дат само облик презента сазидам (448). За глагол пресипати у П93 и П10 упућује се на глагол сипати (имп. сuпај и сипљи - П93: 465; П10: 450 - као мање обичан и рег.).

У наведеној табели нисмо дали преглед стања у Матичиним приручницима из 1993. и 2010. јер су дати само свршени облици глагола (нпр. са упућивањем на гл. знати). У правописном речнику приручника Симић и др. из 1993. глагол надати је забележен, али није дат и у императиву. У Симићевом приручнику из 2016. императиви глагола дати, предати (се) и удати (ce) наведени су у Упутству за писање $J$ у императиву (Симић 2016: 98).

Постојање различитих презентских основа и то пре свега основа на - $a$ довело је, вероватно, и до нестандардних облика типа давај (од давати, са несистемском през. основом дава-) са наставком -j (-jмо, -jmе) који се иначе додаје на презентске основе њихових свршених парњака, нпр. дати - имп. дај (по аналогији *давати - имп. давај). Нпр.: Пустите да мале ствари иду својим током и не придавајте им велику пажњу (Лепа реч, децембар 2020).

Правописни приручници (нпр. П60: 264; 619) бележе и глаголе попут додати и препознати, чији су презентски облици додам/додаднем (през. основе дода-/додадне-) и препознам/препознаднем (през. основе препозна-/препознадне-), па су императивни облици додај (додајмо, додајте) и додадни (додаднемо, додаднете) и препознај (препознајмо, препознајте) и препознадни (препознаднемо, препознаднете). 


\begin{tabular}{|c|c|c|c|c|c|c|c|c|c|c|c|c|c|}
\hline \multirow{5}{*}{ 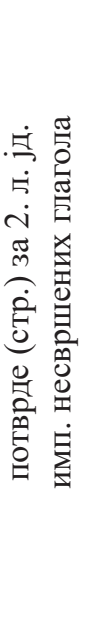 } & $\stackrel{0}{U}$ & 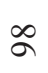 & - & - & - & - & - & - & - & - & - & $\stackrel{\infty}{\sigma}$ & - \\
\hline & $\stackrel{n}{E}$ & - & - & - & $\widehat{\widetilde{N}}$ & - & - & - & - & - & - & బై & $\gamma$ \\
\hline & $\hat{\jmath}$ & $\gamma$ & $\gamma$ & - & $\gamma$ & - & - & $\tilde{\Omega}$ & $\gamma$ & - & - & ๙̃ & - \\
\hline & 음 & 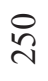 & - & - & సิ & - & - & ڤ̆ & - & - & - & $\hat{n}$ & $\hat{8}$ \\
\hline & $\begin{array}{l}\text { ㅇ } \\
n\end{array}$ & రె & $\stackrel{ }{I}$ & $\stackrel{ }{I}$ & $\frac{\bar{v}}{2}$ & $\underset{\sim}{\sim}$ & $\stackrel{\infty}{\sim}$ & $\frac{\infty}{m}$ & - & ñ & 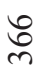 & 으 & - \\
\hline \multicolumn{2}{|c|}{$\begin{array}{l}\dot{\Xi} \\
\dot{\theta} \\
\dot{\Xi} \\
\text { ¿ }\end{array}$} & 莺 & 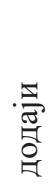 & 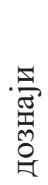 & 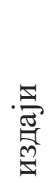 & 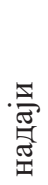 & 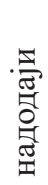 & . & 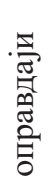 & 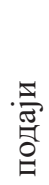 & 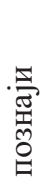 & 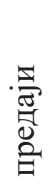 & 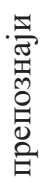 \\
\hline \multicolumn{2}{|c|}{ 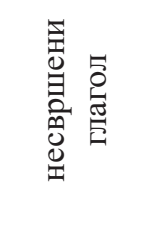 } & 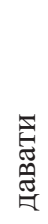 & 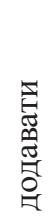 & 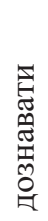 & 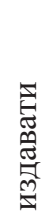 & 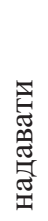 & 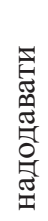 & 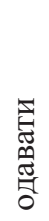 & 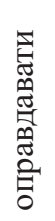 & 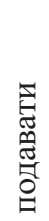 & 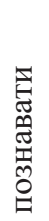 & 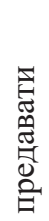 & 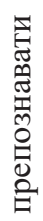 \\
\hline \multicolumn{2}{|c|}{ 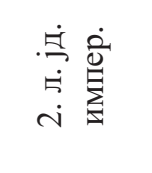 } & 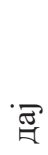 & 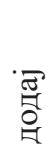 & 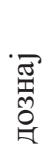 & 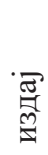 & 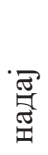 & 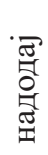 & 㞼 & 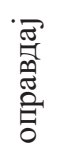 & 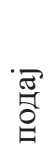 & $\begin{array}{l}\text { 呇 } \\
\text { 品 }\end{array}$ & $\begin{array}{l}\mathbb{\Xi} \\
\mathbb{J} \\
\text { : } \\
\text { : }\end{array}$ & 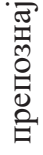 \\
\hline \multicolumn{2}{|c|}{ 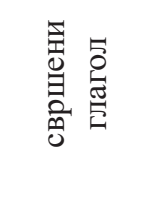 } & $\underset{\mathbb{E}}{\mathbb{E}}$ & 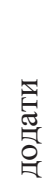 & 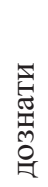 & 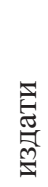 & 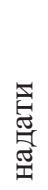 & 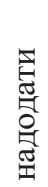 & $\begin{array}{l}\vec{E} \\
\text { E్ } \\
\text { J }\end{array}$ & 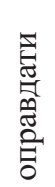 & 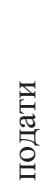 & 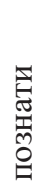 & 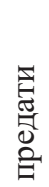 & 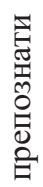 \\
\hline \multicolumn{2}{|c|}{ ن } & $-\dot{-}$ & ن & $\dot{m}$ & $\dot{\nabla}$ & $\dot{v i}$ & $\sigma^{\circ}$ & $\sigma^{\circ}$ & $\infty$ & $\sigma^{\circ}$ & 으 & $\doteq$ & 工 \\
\hline
\end{tabular}




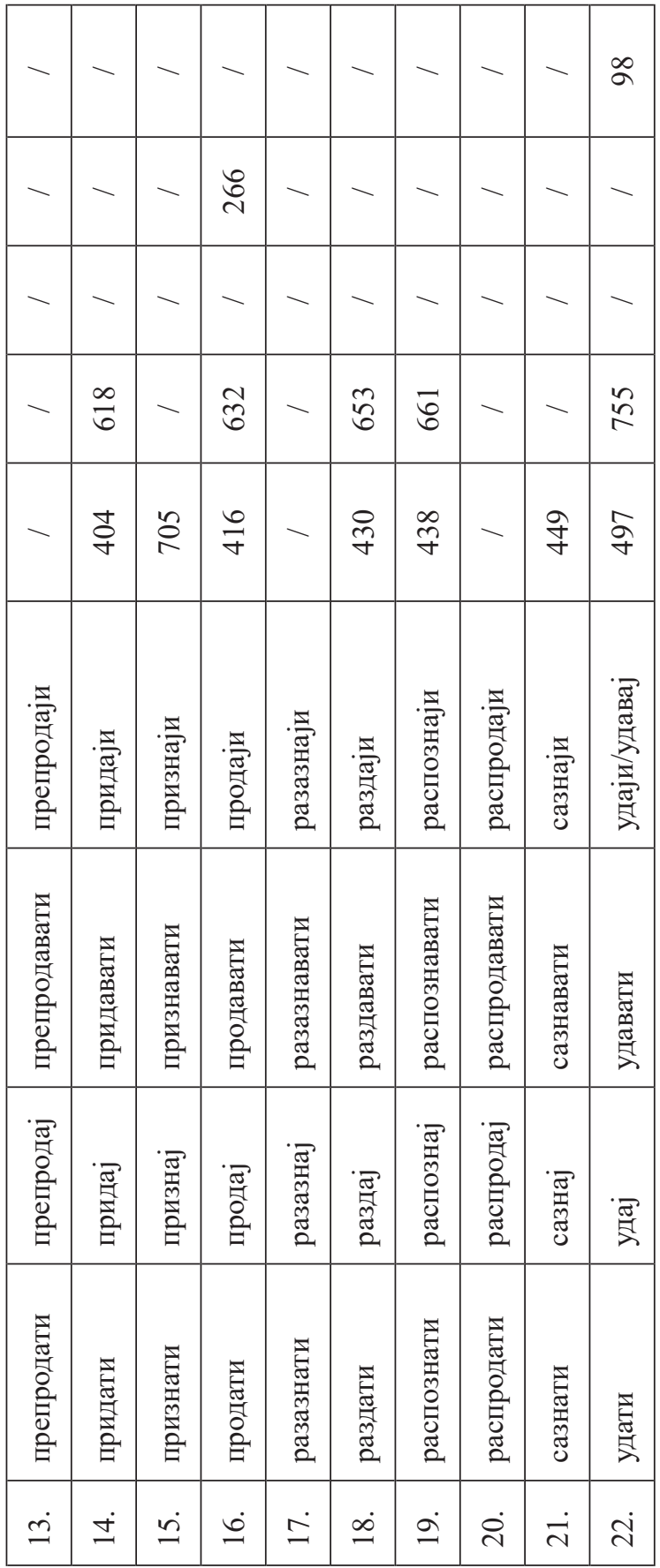




\section{Закључак}

У ери масовног оглашавања императивни облици нашли су своје важно место. Купац мора бити привучен рекламом производа који је на тржишту, а то прати агресивна кампања где је овај глаголски облик одговарајући. Купац се позива да бира, купи, сакупи, освоји, проба, спакује, миксује, не пропусти, нађе, донесе, прегледа, узме неки производ, а поменути глаголи већином су у 2. лицу једнине и у мањој мери у 2. лицу множине императива. Ако томе додамо и један број глагола фреквентан у говорној пракси у овом облику, употпуњује се слика о томе да је императив веома важан глаголски начин са више супстандардних решења у говору и писању. Као извор за анализу послужили су нам правописни приручници српског (српскохрватског) језика које смо користили да бисмо испитали у којој мери је у њима заступљен овај глаголски облик. Анализирани су правописни приручници, јер би они требало да буду консултовани у говорној, писаној, али и наставној пракси (Зељић 2009). Анализа група које смо формирали показала је у великој мери да су супстандардни ликови настали аналошки, и то у једном правцу редукцијом гласовне структуре (изостанком сонанта j) у овом глаголском облику попут покри (се) ум. покриј се, сави (се) ум. савиј (ce), односно, у другом правцу, додавањем финалног самогласника $u$ попут обоји ум. обој, те разуми ум. разумеј, чиме смо добили још један, видели смо већи, број глагола који се у 2. л. једнине завршавају тим гласом. Оба супстандардна решења аналошки су уједначена са стандардним облицима глагола типа доћu (имп. дођи, исто реци , сеци, види, носи и сл.) са самогласником и у наставку за облик. На крају, анализа императивних облика видских парњака показала је да се опет аналошки, јављају нестандардна решења типа давај (од давати, са несистемском през. основом дава-) са наставком -j (-jмо, -jmе) који се иначе додаје на презентске основе њихових свршених парњака.

На крају, да додамо: у правописним приручницима који теже да буду функционални, морало би се, ипак, више пажње посветити и супстандардним решењима, као што је то већ урађено у уџбеничкој литератури (Ломпар 2011; 2014). Неопходна су нам, зато, практична издања правописа, попут школских (сетимо се само Матичиних, в. и Јерковић/Вујовић 2012), који нису били намењени само наставној пракси, већ су били практични и корисни приручници свима онима којима су језик и његова норма део свакодневице. 
ИЗВОРИ

Ало, 25. 11. 2020: https://www.alo.rs/vesti/drustvo/nije-vasa-sramota-ukoliko-vas-zlostavljaju-budite-glasne-i-hrabre-ne-opravdavajte-nasilje/359726/vest, посећено 15. 12. 2020.

Београдски портал, 19. 9. 2020: https:/www.beogradskiportal.rs/2020/09/19/ isprozivao-mrkelu-i-stankovica-amateru-pokri-se-usima-i-cuti/, посећено 12. 12. 2020.

Блиц, 21. 2. 2006: https://www.blic.rs/biznis/otkrite-sve-skrivene-troskove/ g4e4eyl, посећено 12. 12. 2020.

Вукомановић 2016: Л. Вукомановић, Обоји Београд, Београд: Дечји културни центар. Глоси, 10. 2. 2020: https:/glossy.espreso.rs/zdravi-i-srecni/ recepti/167931/za-najlepse-poslastice-iz-vase-kuhinje-3-recepta-za-savrsenu-koruza-kolace-i-torte, посећено 15. 12. 2020.

Лепа реч (месечник), децембар 2020: https://www.leparec.org/5-stvari-kojesvaka-mlada-mora-znati-o-organizaciji-vencanja/, посећено 20. 12. 2020.

Мелвил 1969: Моби Дик, Београд: Народна књига.

Мелвил 2020: Моби Дик, Београд: Лагуна.

Михаиловић 1994: Д. Михаиловић, Петријин венац, Београд: БИГЗ.

Нушић 1996: Бранислав Нушић, Сумњива лицุа, Београд: Српска књижевна задруга.

Телеграф, 7. 9. 2020: https://www.telegraf.rs/sport/tenis/3234219-boris-beker-novak-djokovic-instagram-poruka-us-open-diskvalifikacija/komentari/posalji, посећено 12. 12. 2020.

Топспид (месечник), децембар 2020: https:/www.topspeed.rs/vesti/litre-brojigorivo-osvoji-nova-mol-nagradna-igra-4100.html, посећено 27. 11. 2020.

Кристи 2005: А. Кристи, Херкулови задацฺи, Београд: Политика - Народна књига.

\section{ЛИТЕРАТУРА}

Белић 1923: А. Белић, Правопис српскохрватског кюижевног језика, Београд: Издавачка књижарница Геце Кона.

Белић 1930: А. Белић, Правопис српскохрватског књижевног језика, Београд: Издавачка књижарница Геце Кона.

Белић 1934: А. Белић, Правопис српскохрватског кюижевног језика, Београд: Издавачко и књижарско предузеће Геца Кон А. Д.

Белић 1952: А. Белић, Правопис српскохрватског књижевног језика, Београд: Просвета.

Брборић 1997: В. Брборић, Ортографске, синтаксичке и морфолошко-ортоепске грешке у употреби глаголских облика, Језик данас, 2/1997, 16-20. 
Брборић и др. 1999: Б. Брборић, Р. Гачевић, Ј. Вуксановић (прир.), Картотека језичких недоумица, Београд: Одбор за стандардизацију српског језика.

Дешић 2015: М. Дешић, Правопис српског језика, иколско издање, Београд: Klett.

Зељић 2009: Г. Зељић, „Правописни речник у настави и уџбеницима српског језика", Иновачије у основошколском образовању - вредновање (зборник радова ур. И. Радовановић, Б. Требјешанин), стр. 297-308, Београд: Учитељски факултет.

Зељић 2020: Г. Зељић, Правопис и кюижевнојезичка норма, Београд: Учитељски факултет.

Ивић и др. 2004: П. Ивић, И. Клајн, М. Пешикан, Б. Брборић, Српски језички приручник, Београд: Београдска књига.

Јерковић/Вујовић 2012: Ј. Јерковић, Д. Вујовић, Школски правопис српскога језика, Београд: Школа плус.

Караџић 1818: В. Караџић, Српски рјечник истолкован њемачким и латинским ријечима, Беч.

Лалевић 1980: М. С. Лалевић, Српскохрватски у мом цепу - наша колебања, Зајечар.

Ломпар 2011: В. Ломпар, Српски језик за осми разред основне школе, Београд: Klett.

Ломпар/Антић 2014: В. Ломпар, А. Антић, Српски језик и књижевност за други разред гимназија и средюих стручних школа, Београд: Klett.

Маретић 1899: Т. Маретић, Граматика и стилистика хрватскога или српскога књижевног језика, Загреб: Књижара Л. Хартмана.

Николић 2000: М. Николић, Обратни речник, Нови Сад - Београд: Матица српска, САНУ, Палчић.

Пешикан и др. 1993: М. Пешикан, Ј. Јерковић, М. Пижурица, Правопис српскога језика. Нови Сад: Матица српска.

Пешикан и др. 2010: М. Пешикан, Ј. Јерковић, М. Пижурица, Правопис српскога језика. Нови Сад: Матица српска.

Пипер/Клајн 2013: П. Пипер, И. Клајн, Нормативна граматика српског језика, Нови Сад: Матица српска.

Симић 1991: Р. Симић, Српскохрватски правопис, Београд: Научна књига.

Симић и др. 1993: Р. Симић, Ж. Станојчић, Б. Остојић, Б. Ћорић, М. Ковачевић, Правопис српскога језика са речником, Београд - Никшић: Штампа Унирекс.

Симић и др. 1998: Радоје Симић (ур.), Правописни приручник српског књижевног језика, Београд: Научно друштво за неговање и проучавање српског језика.

Симић/Јовановић 2007: Р. Симић, Ј. Јовановић, Српска граматика, Београд: Јасен.

Симић 2016: Р. Симић, Српски правопис, Београд: Научно друштво за неговање и проучавање српског језика - Јасен. 
Стакић 2010: М. Стакић, О грађењу императива у српском језику, у Морфо(но)лошке теме, Београд: Чигоја штампа.

Станић 1973: М. Станић, За културу језика, Београд: Завод за уџбенике и наставна средства.

Станић/Морачић 1989: М. Станић, И. Морачић, Језичко правописни саветник, Београд: Научна књига.

Стевановић/Јонке 1960: М. Стевановић, Љ. Јонке (ур.), Правопис српскохрватскога книжевног језика, Нови Сад - Загреб: Матица српска - Матица хрватска.

Стевановић 1986: М. Стевановић, Савремени српскохрватски језик, књ. 1, Београд: Научна књига.

Goran N. Zeljić

\section{IMPERATIVE FORMS IN ORTHOGRAPHIC HANDBOOKS OF THE SERBIAN LANGUAGE}

\section{Summary}

The paper analyzes the representation of imperative forms in the orthography of the Serbian (Serbo-Croatian) language, starting from Belić's handbooks (1923, 1930, 1934, 1950), through Matica's editions (1960, 1993, 2010), concluding with Dešić's (2015) and Simić's handbook (2016). The analysis includes a hundred verbs that appear in the mentioned handbooks in the imperative form, and which also have substandard forms in spoken and written practice. All of them are divided into four groups, having in mind their forms of imperatives. Those are: a) verbs in which in the imperative there is a non-standard loss of the sonant $j$ from the suffix for the form (eg. zali instead zalij, pokri (se) instead pokrij se); b) Verbs that in the forms of imperatives have non-standard $i$ after the suffix $-j$ (eg. boji instead boj, oboji instead oboj); c) Verbs with doublet forms of imperatives (eg. vagaj and važi, dozidaj and doziđi); d) Verbal aspect pairs and their forms of imperatives (eg. dati-daj: davati-daji, prepoznatiprepoznaj : prepoznavati - prepoznaji).

Key words: verb forms, imperative, orthography, orthographic dictionary. 